Research article

\title{
Geopolitical Situation in Northeast Asia: Development of Sino-Russian Relations
}

\author{
M. Zreik \\ Central China Normal University \\ No.152, Luoyu Road, 430079, Wuhan, Hubei, People's Republic of China
}

\begin{abstract}
The purpose of this paper is to explore the nature and characteristics of Sino-Russian relations since 1640 where diplomatic and commercial relations were established in the far east of Siberia. A historic background will be given, in order to highlight the real reasons behind this good relation that is turning into an alliance. The paper will shed the light on important events and dates that occurred in this relation, such as the year 1858, which had disputes on the border. The author shows that the relations between China and Russia have been faced with twists and turns since its beginnings because of geographical, cultural, historical and political interdependence. This paper analyses the relationship between Russia and China in the light of international political changes as the world enters a new stage of international order, especially after the decline of US influence and China's announcement of its One Belt One Road initiative (OBOR) and its political, cultural and economic openness to the world.
\end{abstract}

Keywords: Northeast Asia, China, Russia, New World Order, Communism, Belt and Road Initiative

\section{Introduction}

Historical experience shows that neighboring countries that share common borders in most cases do not have friendly relations, especially if they are militarily strong and aspire to become regional or international powers. The hostility between Pakistan and India arose from a territorial dispute over the Kashmir region and resulted in an armed conflict at their border. The Arab-Israeli conflict is another example. The Arabs demand that Israel should withdraw its military forces, while Israel is trying to convince the international community that the danger is coming from the Arabs and that they pose a threat to its national security. Yet another example is a number of international conflicts related to the status of Kurdistan. The Kurds are an ethnic minority that has been in conflict with a number of regional powers, Iran and Turkey being the major ones.

International relations have never been steady, and this is very unlikely to change in the future. Sometimes seemingly good relations, based on cooperation and partnership, hide intentions of less benevolent character. Logically, every state pursues its own interests and interests of its people. The concerns of other countries, even those with shared borders, will not be a priority on its agenda. Different governments pursue

\section{Zreik M., 2019.}

(c) (1) This work is licensed under a Creative Commons Attribution 4.0 International License https://creativecommons.org/licenses/by/4.0/ 
different goals, and unless there is a common interest (of economics, security or of a different nature), mutually beneficial relations will not be established.

The relationships between China and Russia date back to 1640, when diplomatic and commercial relations were established in the far east of Siberia [1. P. 182, 183]. Since then, Sino-Russian relations have experienced a number of twists and turns. At times, the alliance was strong, at other times, there were rather palpable tensions between the two nations. At a certain point, the frictions reached their peak and resulted in a military conflict. At the time, China allied with the United States for fear of their strong Soviet neighbor [2. P. 12]. However, after certain critical global developments, such as the fall of the Soviet Union, China's economic rise, and the United States turning into a leading superpower, Beijing set a course for establishing a closer rapport with Moscow. These days, the Sino-Russian convergence keeps growing, and the two countries have formed a strategic alliance, particularly after China launched its One Belt One Road initiative.

This paper will examine the essence and evolution of Sino-Russian relations through the analysis of documents, scientific evidence and official statistics. Ultimately, the article attempts to find an answer to the question "Why did the relationship between Russia and China become a strategic alliance after the collapse of the Soviet Union?"

In order to answer this question, the author conducts a qualitative case study, followed by a comparative analysis of the relationship between China and Russia before and after the collapse of the Soviet Union. To determine the reasons for this shift in the two countries' liaisons, the article focuses on the current stage of the Sino-Russian bilateral relationship. In his query, the author refers to various historical documents, government sources and other materials, such as interviews, books and opinion articles.

\section{Historical Background}

Sino-Russian relations date back to 1640 [1. P. 182, 183], when diplomatic and trade relations were established in the far east of Siberia. However, the relations were not ideal because of border disputes. In 1858, Russia included the Amur River (which delineates the border between Russia and China) and Vladivostok in its geographical region [3. P. 12] after which the tensions between the two countries have been constant. The Communist regime in Russia, same as in China, was based on unified principles of social justice and elimination of classes. The Soviet Union's role in supporting the Asian peoples in establishing the Communist system is undisputable. China, in particular, received a lot of development aid from the USSR. In the early 1960s, when the Soviet aid to China was cut off as per Khrushchev's decision [4. P. 10], the country sunk into a state of economic decline, unemployment and poverty. After the triumph of the Chinese revolution, Russia offered China its patronage, however, things between the two countries went sour due to certain ideological tensions and border clashes, which, eventually, amounted to a threat of a war. On June 30, 1960, the Soviet Union and China announced an ideological rupture between them [5. P. 769]. The Soviet experts were suddenly withdrawn from China, and, concurrently, the first border dispute broke out.

Many Chinese political analysts believe that China's communist principles that have been observed and maintained ever since Lenin's departure is the correct one. 
The Soviet-Chinese ideological divergence along with border disputes were inevitably leading to the two states' political break-up that would have ramped up the collapse of the Soviet Union and made China a fragile and fragmented state at the time. The shape of the world and international order today would not be the same "if the Russian bear had not joined together with the Chinese dragon". But the Russians quickly acknowledged the fact that abandoning China was a historic mistake. After the collapse of Soviet Union, China proved to be a true economic and political partner to the exhausted Russia. At the beginning of the 1990s, Russia was economically devastated. Timely, Beijing increased its economic cooperation with Moscow, recognizing an opportunity for economic growth and also started a military partnership with Russia. In its turn, Russia agreed to this partnership because of the necessity to re-build its wrecked economy, seeing China as a long-term future partner. Reciprocating the aid it received from the Soviet Union in the past, China pledged its support to Russia, which heralded a new period in the history of the Sino-Russian relations, that of economic, military and diplomatic cooperation, neighborly relations and mutually beneficial alliance to counter the western policies.

\section{The International Status of Russia and China within the Framework of the US-Ied System}

The rising "Chinese dragon" and the "Russian bear" have a long and controversial relationship history. Nowadays, Sino-Russian relations are close and cordial but based primarily on economic and security interests. To a large extent, the current Sino-Russian good rapport is the result of their opposition to U.S. pressure. The Russian Federation, which superseded the Soviet Union, is one of the most influential military powers in the world with U.N. veto authority. China, along with the U.S., is the most powerful economy on the globe, at the same time it has a strong army and is endowed with U.N. veto power. Despite the collapse of the Soviet Union, Russia remains the indisputable leader of the Eastern camp, as became obvious during the Syrian crisis, when the Russian leadership made a decision to support the Syrian regime militarily and politically. On September 30, 2015, in response to the Syrian President Bashar al-Assad's request for military support from Moscow to stop the rebellious terrorist groups, Russia directly intervened in the Syrian war [6]. The Russian Federation Council approved President Vladimir Putin's authorization to use national armed forces outside the country and the Russian air force launched air strikes on the Syrian territory.

The United States remains the most powerful country in the world, leading the Western camp and directly or indirectly influencing other nations' political, military, and economic decisions. Today, the United States has 750 military bases in 130 countries, and they are located in the most strategically important areas [7]. Currently the United States is working on expanding its influence in one of the most coveted geopolitical regions of today, the South China Sea [8]. The United States is also a member of the North Atlantic Treaty Organization (NATO), the "military arm" of the Western countries; and when the American government plans its military campaigns, it counts on the support of its Western allies.

The military conflict in Ukraine clearly demonstrates the underlying motives in American foreign policy, directed against Russia's international image and political standing. In 2014, Russia began military operations in the Ukrainian territory. After 
protests in Kiev and the removal of Ukrainian President Viktor Yanukovych, Russian troops took control of vital strategic sites in Ukraine's Crimean region, before formally annexing the peninsula after Crimeans voted to join the Russian Federation in a local referendum [9]. Pro-Russian demonstrations were then organized by separatist groups in Donbas [10], leading to an armed conflict between the Ukrainian government and the Russian-backed separatist forces. Former US national security adviser Zbigniew Brzezinski said: "If Ukraine falls from the hands of Russia, Russia must forget that it is a superpower" [11].

Russia is one of the major players on the international stage and carries a lot of weight in the distribution of the global power. The international campaign in Ukraine has resulted in the re-annexation of the Crimea to the Russian Federation [12]. As for Washington's hidden motives in its relations with China, the United States has always sought to reopen the sensitive issues, such as Taiwan, Hong Kong and the South China Sea, and the latest move by the administration of US President Donald Trump was starting a trade war against China.

Being one of the major global economies with a strategically influential geographical position, the United States carries a great authority in the world's economy, politics, military affairs and technology. Today China's economic influence has ratcheted up, making it the second largest economy on the globe [13]. At the same time, Beijing is constantly trying to strengthen its military potential. China's growing international success has substantial strategic implications for U.S. interests and presents a risk for America's international standing. China's economic influence makes Beijing's political decisions crucial for a lot of countries in Asia, Africa, Europe and Latin America. The PRC is also the largest creditor of the United States (which is currently experiencing an unprecedented budget deficit) with an estimated $\$ 1.3$ trillion in the form of treasury bonds [14].

According to some economic analysts, America's heavy indebtedness is the main source of Chinese economic influence on the United States. The United States, in its turn, has been trying to manipulate China by turning the global attention towards certain human rights issues in some of the Chinese provinces, such as persecution of Buddhists in the Tibet Province, and the detention of Uighur Muslims in the Xinjiang Province. One of the examples of the human rights abuse by China is heavy restrictions imposed on the use of the internet by Chinese people.

The United States will support its ally Japan in the Sino-Japanese territorial conflict regarding the Senkaku Islands (called so by the Japanese), or the Diaoyudao Islands (called so by the Chinese) [15. P. 10-13]. In regards to the Taiwan question, PRC asserts that there is only "one China", and that Taiwan is an inalienable part of it, which the United States seems to disagree with. The United States made Taiwan its "Cold War" ally by providing military training and supplying weapons to the Taiwanese army. In regards to the dispute over the South China Sea, the situation is similar: China claims the sea is part of its territory, and the United States begs to differ. The South China Sea is considered to be one of the world's largest seas, with strategically important maritime routes. More than a third of the global shipping traffic goes through its waters, with the commercial value of these shipments being more than five trillion dollars [16]. It is also believed to have large reserves of gas and oil [17]. 


\section{Sino-Russian Relations after the Collapse of the Soviet Union}

Modern diplomatic relations between China and the Soviet Union were established in 1949, when with the Soviet support of the People's Republic of China was established. The Soviets were the first to recognize the PRC as an independent state. Further on, with ideological tensions, the relations started worsening, resulting in seven-monthslong military clashes between the Soviet Union and China in 1969. China's growing ambitions threatening the Soviet superpower eventually turned allies into adversaries [18] and resulted in China's teaming up with the United States. The hostile relations lasted until 1991, when the border agreement was signed, and the Sino-Russian rapprochement began. Today China and Russia have an excellent relationship within the framework of the Shanghai Cooperation Organization and share the same strategic vision.

In the field of military cooperation, the two countries have carried out a number of joint anti-terrorist army drills and numerous coordinated anti-drug trafficking activities. The year 2006 was proclaimed the "Year of Russia" in China, and, in kind, the year 2007 was declared to be the "Year of China" in Russia. Approximately 550 educational, sports and social activities were hosted in the two countries on these occasions. In 2006-2007, Beijing and Moscow started an active cooperation in trade, finance and energy. Numerous Chinese-Russian seminars were held for representatives of the business sector. The two nations' commodity exchange in 2008 increased by 38.7 percent (to $\$ 55.9$ billion), as compared to 2007 . In the same year, Russian exports to China increased by 33 percent, Russian imports from China increased by 42.3 percent, and Russia's negative trade with China reached $\$ 13.5$ billion. The ties between 70 Russian and 26 Chinese provinces and territories are developing effectively, and both countries are expecting to raise the trade volume to $\$ 200$ billion by 2024 [19].

China and Russia have been conducting joint military exercises since 2005 in the framework of the Shanghai Cooperation Organization, which also covers Kazakhstan, Kyrgyzstan, Tajikistan and Uzbekistan. The organization calls for strengthening of regional cooperation and is aimed at countering US influence. On April 22, 2012, the first joint naval military exercises between Russia and China were launched near the Chinese coast. China deployed two submarines, 16 ships and more than 4,000 troops, while Russian forces sent seven ships including destroyers, cruisers and missiles [20]. The treaty of "Good Neighborliness and Friendly Cooperation" signed between China and Russia on July 16, 2001 is the basis for the development of bilateral relations between the two countries ${ }^{2}$.

The shared Communist ideology was not a deterrent to the Soviet-Chinese dispute, because China felt that the Soviet Union had begun to pose a threat to its national security and strategic interests, and, therefore, allied itself with the enemy (the United States) to weaken the Soviet neighbor. The liberal and democratic United States welcomed the new Communist friend (China) because it needed a foothold near the Soviet Union. Thus, China secured its borders from the Soviet threat and the United States had an indirect control of the Soviets through the neighboring China.

2 The Treaty of Good-Neighborliness and Friendly Cooperation between the People's Republic of China and the Russian Federation (FCT) is a twenty-year strategic treaty that was signed by the leaders of the two international powers, Jiang Zemin and Vladimir Putin on July 16, 2001. 


\section{Strong Chinese State in Russian Eyes}

Today, China is turning into a great power, mainly owing to the "open door" policy pursued by Chinese leader Deng Xiaoping [21] and the existing unique socialist system, with peculiar Chinese characteristics, which make it different from the classic socialist and liberal systems. Beijing today allocates a large proportion of its budget to armament. At the same time, China's per capita income has surpassed Russia's per capita income and currently China is working on its economic expansion, launching different projects, such as One Belt One Road Initiative. To sum up, after the collapse of the Soviet Union, China has been on a constant rise, while the Russian economy remains weak in comparison, however, the Russian military arsenal is still excellent.

China and Russia are two great powers that are endowed with the power of veto and possess a huge geopolitical, military and human potential. Strategically, Russia is the military wing of the Eastern Alliance, while China is its economic wing; although China has one of the most powerful armies in the world and is constantly developing its military strength in parallel with its impressive economic growth. Russia accepted China's non-military expansion to Central Asia (the region is in dire need of economic and development projects) reluctantly [22]. In some central Asian countries, the Chinese Yuan replaced the Russian ruble as the primary currency [23].

The One Belt One Road initiative, launched by Chinese President Xi Jinping in 2013, aims to make China an "economic pump" and an international trading center by means of building extensive sea and land networks that would link China to the rest of the world. However, the implementation of this initiative would not have been possible without Russian approval of Chinese expansion [24], including access to roads in the Central Asian region and the new Eurasian bridge. In other words, but for the Russian recognition of China as a strong neighbor and the necessity of an alliance to counterbalance its historic enemy, the USA, China would not have become a superpower. Among China's motives for convergence with Russia were the shared geographical borders and the need to have a strong and long-term ally, especially in the light of the recent trade war launched by US President Donald Trump and the systematic US campaigns against China with regard to the Uighurs and the South China Sea region. The Sino-Russian alliance is an imperative for China's economic renaissance. Numerous Russian and Chinese companies have signed bilateral contacts related to the development of trade and economic cooperation, while the number of two-sided investments has also increased.

In this context, according to a statement issued by the Russian Direct Investment Fund, 73 projects with a total value of more than $\$ 100$ billion are being studied on the sidelines of the "Russian Economic Forum" [25]. A joint China-Russian trade advisory committee is working on surveying various projects in the fields of industrial production, infrastructure, metal processing, agriculture, etc. Meanwhile, seven projects with a total value of $\$ 4.6$ billion have already been implemented as a result of Russia-China cooperation. "With steady economic growth in Russia and China, there are plenty of lucrative investment opportunities in the domestic markets, but we believe that the promising deals will emerge from bilateral relations", said Kirill Dmitriev, president of the Russian Fund [26]. 
China has replaced the EU as Russia's largest trade partner in the last two years, acquiring 15 percent of Russia's overall foreign trade. The volume of trade between the two countries rose by 31.5 percent in 2017 compared to 2016, reaching an unprecedented $\$ 87.4$ billion, of which $\$ 39$ billion were Russia's exports and to China, while the imports' worth amounted to $\$ 48.4$ billion. Both sides expect trade volume to exceed the 100 billion mark by the end of this year, according to an ambitious plan to push for 150 percent exchange over the next ten years. Russian President Vladimir Putin expressed his satisfaction with the fact that the volume of the bilateral trade between the two countries is rising by 30 percent annually [27].

Recently, the cooperation has expanded to new areas, which previously were not on the agenda, such as the communications and internet sectors. China's largest internet group Alibaba has tied up a deal with a group of Russian technology companies with a view to establish an e-commerce giant operating on the territory of Russia and the Commonwealth of Independent States [28]. The agreement was signed between Alibaba, Megaphone, Mail.Ru and the Russian Direct Investment Fund in the framework of the East Economic Forum in Vladivostok [29]. The deal, the first of its kind in Russia's retail sector, is supposed to be completed in the first quarter of the next year. This is an indication that Moscow has already begun to implement a policy of switching its partners in the field of digital technology and communications, with China replacing Western companies that withdrew from the Russian market or froze their activities due to the sanctions imposed on Moscow.

Chinese President Xi Jinping stressed the necessity to build strong relations between China and Russia and increase joint cooperation in the areas of energy and innovation. According to the Chinese leader, the link between One Belt One Road initiative and the Eurasian Economic Union should be further strengthened, while the comprehensive partnership between the two states should be reinforced and coordinated. The idea proposed by Chinese Foreign Minister Wang Yi to build a Sino-Mongolian-Russian economic corridor [30] across the entire Eurasian continent is a proof of China's intention to strengthen its political and economic influence with Russian support and coverage.

\section{New World Order from the Chinese-Russian Perspective}

The mutually beneficial Sino-Russia alliance, which emerged during the Syrian crisis, has resulted in the establishment of the BRICS and, more recently, Russia's active accession to One Belt One Road initiative. Russian President Vladimir Putin declared that Russia supports Chinese ambitions and hopes to find a model of cooperation to launch Russia - China joint projects on the Trans-Siberian Highway and the BaikalAmur road.

Russia and China are seeking ways to exclude foreign currencies, such as the dollar, from their cooperation, which would be "the starting step to reduce the dollar's dominance of the world" [31]. "The Russian and Chinese sides have stressed their interest in promoting the use of national currencies in trade accounts, which will ensure the stability of banking services for export and import operations, in view of the growing risks in global markets", said the Russian president. 
Experts on both sides believe that major difficulties are still ahead, but the mutual Russian-Chinese effort in the direction of strong multi-dimensional partnership reflects a serious trend in the global arena. However, although such a course of events was inevitable, it is certainly not going to be rapid. It is likely that China and Russia will rely mainly on their allies in the SCO and other regional groups [32], as well as countries that are also suffering from the effects of US sanctions.

While Moscow is a lever and an invaluable resource for the Chinese One Belt One Road initiative, Russia equally benefits from its partnership with China. China today is a strategic partner of Russia, strengthening its northern front and allowing it to address the United States and the rest of world from a solid and strong position.

\section{Conclusion}

Throughout history, Sino-Russian relations have gone through many ups and downs. Although the two countries shared the Communist ideals and governance model, at times, their national, geographic and security interests pushed the nations to act against each other. With the change of international order, the fall of the Soviet Union and the United States establishing a dominant rule in international politics, China reconsidered its relations with the Russian neighbor in favor of a strong economic and geopolitical alliance, especially in view of its rapid economic growth and the One Belt One Road initiative.

\section{References}

[1] Young E. The Presidency of Yuan Shih-K'ai. University of Michigan Press; 1977: 182-183.

[2] Alles E., Cherif-Chebbi L., Halfon C.H. Chinese Islam: Unity and Fragmentation. Religion, State \& Society. 2003; Vol. 31 (1): 7-35. DOI: 10.1080/0963749032000045837.

[3] Nyíri P., Breidenbach J. ed. China Inside Out: Contemporary Chinese Nationalism and Transnationalism. Central European University Press; 2005. 369 p.

[4] Current Intelligence Staff Study, the New Stage of the Sino-Soviet Dispute (October 1961 January 1962) (Reference Title: ESAU XVII-62). 26 February 1962 OCI No. 0361/62 Copy No. 133. Approved for Release Date: May 2007.91 p. Central Intelligence Agency library (CIA). Available from: https://www.cia.gov/library/readingroom/docs/esau-16.pdf. Accessed: 01.10.2018.

[5] Lenman B.P., Anderson T. Chambers Dictionary of World History. Editors, Chambers: Edinburgh; 2000. $950 \mathrm{p}$.

[6] McDonnell P.J., Hennigan W.J., Bulos N. Russia Launches Airstrikes in Syria amid U.S. Concern about Targets. Los Angeles Times. 30.09.2015.

[7] Army Base Guide List, United States. Available from: https://www.military.com/base-guide/browseby-service/army. Accessed: 01.10.2018.

[8] Crawford J., Sciutto J., Schwarz T. U.S. Protests after Chinese Military Jet Lands on South China Sea Island. CNN - CNNPolitics.com. 19.04.2016. Available from: https://.edition.cnn.com/ 2016/04/18/politics/chinese-military-jet-lands-on-island. Accessed: 01.10.2018.

[9] Morello C., Constable P., Faiola A. Crimeans Vote in Referendum on whether to Break away from Ukraine, Join Russia. The Washington Post. 14.03.2014.

[10] In Eastern Ukraine, a One-Building, Pro-Russia Realm Persists Despite Criticism. The New York Times. 09.04.2014.

[11] Interview with Zbigniew Brzezinski on Russia and Ukraine. Spiegel online. 02.06.2017. Available from: https://www.spiegel.de/international/world/interview-with-zbigniew-brzezinskion-russia-and-ukraine-a-1041795.html. Accessed: 01.10.2018. 
[12] Putin Signs Laws on Reunification of Republic of Crimea and Sevastopol with Russia. ITAR TASS. 21.03.2014.

[13] IMF report for China. International Monetary Fund. October 2018.

[14] World Economic Outlook. International Monetary Fund. 2018.

[15] Seokwoo L. Territorial Disputes Among Japan, China and Taiwan Concerning the Senkaku Islands. Boundary and Territory Briefing. 2002; Vol. 3; 7: 10-13.

[16] How much Trade Transits the South China Sea? China Power. 04.08.2017.

[17] McDowell R. A Look at the Top Issues at Asian Security Meeting. Associated Press. 21.07.2011.

[18] Savic B. Behind China and Russia's 'Special Relationship'. The Diplomat. 07.12. 2016.

[19] Russian Government Plans to Boost Bilateral Trade with China to $\$ 200 \mathrm{~B} \ln$ by 2024. Sputnik. 27.09.2018.

[20] Wu D. China and Russia Sign Military Cooperation Roadmap. The Diplomat. 30.06.2017.

[21] Sung Y. The Open-door Policy. The China-Hong Kong Connection: The Key to China's Open Door Policy (Trade and Development). Cambridge: Cambridge University Press; 1991: 5-14. DOI: $10.1017 /$ CBO9780511552298.003.

[22] Sino-Russian Alignment in Reality: The Case of Central Asia. Global Risk Insights. 06.03.2019.

[23] Gleason G. Currency Wars along the Silk Road. The Diplomat. 27.07.2017.

[24] Russia Agrees to Significant Silk Road Projects with China. Russia Briefing. 19.07.2017.

[25] Rosenfeld E. Russia and China Are Looking at Launching Joint Projects Worth more than $\$ 100$ Billion. CNBC World Economy. 11.09.2018.

[26] Chinese-Russian Joint Investments Beneficial: Russian Fund. Interview with Kirill D. Xinhua. 02.05.2018.

[27] China Becomes Russia's Top Trade Partner. Xinhua. 26.09.2018.

[28] Alibaba Ties with Russian Partners for an E-commerce Platform. CNBC. 11.09.2018.

[29] Alibaba, Russian Tech Firm Mail.ru Agree Joint E-commerce Venture. France24. 11.09.2018.

[30] Wang Yi. Introduces the Consensuses Reached at China—Mongolia Foreign Ministers' Meeting. Ministry of Foreign Affairs of the People's Republic of China. 24.08.2018.

[31] Demyanchuk A. Russia \& China Preparing to Ditch Dollar for National Currencies in Trade. $R T$. 18.10.2018.

[32] Guangcheng X. Sino-Russian Ties Backbone of SCO. China Daily. 06.06.2018.

\title{
Article history:
}

The article was submitted on 18.12.2018.

The article was accepted on 15.06.2019.

\section{Геополитическая ситуация в Северо-Восточной Азии: развитие китайско-российских отношений}

\author{
М. Зрейк \\ Классический университет Центрального Китая \\ № 152, Люою Роад, 430079, Ухань, Хубэй, КНР
}

\begin{abstract}
Аннотация. Целью данной статьи является исследование процессов и особенностей китайскороссийских отношений начиная с 1640 г. - даты, когда были установлены дипломатические и торговые отношения между странами. Автор проводит историко-ретроспективный анализ для того, чтобы выявить причины, стоящие за современными стратегическими отношениями двух стран,
\end{abstract}


которые имеют потенциал превратиться в геополитический и геоэкономический союз. В статье рассматриваются отдельные важные исторические события, характеризовавшие исторические отношения двух стран, например, пограничный спор 1858 г. Автор показывает, что отношения между Китаем и Россией с самого начала взаимодействия двух стран развивались в силу географической, культурной, исторической и политической взаимозависимости. В статье анализируются отношения России и Китая в свете международных политических трансформаций, актуализирующихся по мере того, как мир вступает в новый этап формирующегося международного порядка. По мнению автора, трансформации мирового порядка особенно ускоряются в результате снижения международного влияния США и реализации Китаем инициативы «Один пояс - один путь» (OBOR) в рамках его политики политической, культурной и экономической открытости.

Ключевые слова: Северо-Восточная Азия, Китай, Россия, Новый Мировой Порядок, коммунизм, инициатива «Один пояс - один путь»

\section{История статьи:}

Статья поступила в редакцию 18.12.2018.

Статья принята к публикации 15.06.2019.

\section{Информация об авторе:}

Мохамад Зрейк - аспирант школы политики и международных отношений Классического университета Центрального Китая (KHP) (ORCID ID: 0000-0002-6812-6529) (e-mail: mohamadzreik@hotmail.com).

\section{Information about the author:}

Mohamad Zreik — PhD Student, School of Politics and International Studies (SPIS), Central China Normal University (People's Republic of China) (ORCID ID: 0000-0002-6812-6529) (e-mail: mohamadzreik@hotmail.com).

\section{Для цитирования:}

Zreik M. Geopolitical Situation in Northeast Asia: Development of Sino-Russian Relations // Вестник Российского университета дружбы народов. Серия: Политология. 2019. Т. 21 . № 3. C. 450 -459. DOI: 10.22363/2313-1438-2019-21-3-450-459.

\section{For citation:}

Zreik M. Geopolitical Situation in Northeast Asia: Development of Sino-Russian Relations. RUDN Journal of Political Science. 2019; 21 (3): 450 - 459. DOI: 10.22363/2313-1438-2019-21-3-450-459. 